\title{
3 種類以上の薬剤服用時の薬物間相互作用に関する後方視的検討
} 〜岡山県児島地区の保険薬局における多施設共同研究〜

\author{
岡 夏未, ${ }^{a}$ 近藤真志, ${ }^{b}$ 松原秀樹, ${ }^{c}$ 出石啓治, ${ }^{d}$ 田坂祐一 ${ }^{*, a}$
}

\section{Potential Drug-Drug Interactions among Three or More Drugs: A Retrospective Multi-center Study in Pharmacies in the Kojima Region, Okayama}

\author{
Natsumi Oka, ${ }^{a}$ Masashi Kondo, ${ }^{b}$ Hideki Matsubara, ${ }^{c}$ Keiji Izushi, ${ }^{d}$ and Yuichi Tasaka*,a \\ ${ }^{a}$ Laboratory of Clinical Pharmacy, School of Pharmacy, Shujitsu University; 1-6-1 Nishigawara, Naka-ku, Okayama \\ 703-8516, Japan: ${ }^{b}$ With Pharmacy; 1-1-9 Kojimaajino, Kurashiki, Okayama 711-0913, Japan: 'Fuji Pharmacy; \\ 2-7-25 Kojimaajinokami, Kurashiki, Okayama 711-0917, Japan: and IIzushi Pharmacy; \\ 1-88 Kojimaekimae, Kurashiki, Okayama 711-0921, Japan.
}

(Received November 17, 2020; Accepted April 12, 2021)

\begin{abstract}
Drug-drug interactions (DDIs) are responsible for an increase in the incidence of adverse drug reactions. Although CYP is known to be involved in metabolic processes, the DDIs among three or more drugs that involve the same CYP molecular species have not been fully investigated. In this study, we retrospectively examined the relationship between the number of drugs and potential DDIs in metabolic processes involving CYPs in patients who picked up their prescribed drugs at 11 pharmacies in the Kojima Branch of the Okayama Pharmaceutical Association. We found that $66.5 \%$ of the 924 patients had potential DDIs; more than half of the patients who took six or more drugs had potential DDIs among three or more drugs. The mean number of CYP3A4-related drugs involved in potential DDIs was $3.52 \pm$ 1.56 in patients who took seven drugs, suggesting the need for careful monitoring of specific symptoms and blood test results for the early detection of adverse drug reactions caused by DDIs among three or more drugs.
\end{abstract}

Key words — drug-drug interaction; CYP; adverse drug reaction

\begin{abstract}
緒
言

わが国における診療報酬明細書（医科入院外）及 び調剂報酬明細書 1 件あたりの薬剤種類数は院内・ 院外処方ともに平均で 3 種類以上である. ${ }^{1)}$ 特に, 高齢者では加齢による生理的な変化に加え，複数の 併存疾患に対する治療のため服用薬剂数が増加する 傾向にあり，それに伴い薬物間相互作用（drugdrug interaction; DDI) や薬物有害反応（adverse drug reaction; ADR)などが生じ易くなる. 実際に, 65 歳以上の入院患者において, 6 剂以上を服用して いる患者では 1-3 剂を服用している患者に比べ ADR の発生率が有意に上昇することが報告されて いる. ${ }^{2)} \mathrm{ADR}$ は追加薬物治療あるいは入院の増加, 入院期間の延長, 生活の質の低下を引き起こし, 医 療費を増加させる. ${ }^{3,4)}$ 一方, DDI は ADR を増加さ

$a$ 就実大学薬学部臨床薬学研究室, $b$ ウイズ薬局, $c$ 富士 薬局, dいずし薬局

*e-mail: you-tasa@shujitsu.ac.jp
\end{abstract}

せる要因となるが，事前に DDI を確認することに より回避可能な ADR の回避につながる可能性が報 告されている. ${ }^{4,5)}$ したがつて，DDI に関する知見 は臨床現場において極めて重要な医薬品情報の 1 つ である.

DDI の約 $40 \%$ は薬物動態学的相互作用であり, そのほとんどにCYP が関与していると考えられて いる. $\left.{ }^{6}\right)$ また，「医薬品開発と適正な情報提供のため の薬物相互作用ガイドライン」では, 医薬品開発に おける CYP が関与する DDI の検討及び情報提供 は，臨床現場における DDIによるADR の回避に 寄与できるとされている. ${ }^{7)}$ 一方で, 現在の添付文 書に記載がある DDI はいずれも 2 薬剤間に関する ものであり, 実臨床においては 3 種類以上の代謝過 程に同一の CYP 分子種が関与する薬剂が併用され る場合も少なくないと考えられるが，その頻度や影 響は不明である，そのため，現在の DDI に関する 医薬品情報のみでは添付文書に記載がない，あるい は 2 薬剤間の DDI 発生時よりも重篤な副作用が発 
生する可能性は否定できず，医薬品適正使用の観点 からCYP が関与する DDI の実際に関する更なる 知見が望まれる。そこで本研究では，服用薬剤数と 代謝過程における DDI の現状について後方視的に 調査した。

\section{方法}

1. 調查対象 調查対象期間は 2020 年 4 月 6 日-12 日の 7 日間とし，この期間内に岡山県薬剤師 会児島支部に所属する保険薬局 11 施設（いずし薬 局，ウイズ薬局児島店，幸観堂薬局，幸観堂薬局味 野店，児島あい薬局，児島ひかり薬局，サカ工薬局 児島店，富士薬局，ミモザ薬局，らくだ薬局，わか ば薬局駅前店）で調剂を受けた患者を対象とした. ただし，本研究では外用薬及び 1 種類の薬剤のみを 服用している患者は対象から除外した。

\section{2. 調査項目及び調査方法 調査項目は年齢,} 性別及び服用薬剂（一般名，1 回服用量，用法）と し，Microsoft Excel を用いて作成したフォーマッ トに転記する形で収集した。また，これらの情報は 各保険薬局においてフォーマットに入力され，収集 した内容には患者の氏名，生年月日など患者個人を 特定できる情報は含まれない，

3. 解析方法各薬剂の代謝経路は，それぞれ の先発医薬品の添付文書及びインタビューフォーム （IF）を用いて調査した。 また，代謝過程における CYP 分子種の関与は, 阻害・競合・誘導に分類 し，「基質となる」と記載されている場合は競合に 分類した。なお，対象薬剤が配合剤の場合は，含ま れる各有効成分の代謝経路を確認し，それぞれを 1 薬剤として（2 成分が含まれる配合剂であれば 2 薬 剂として）解析を行った。ただし， $\mathrm{PL}^{\circledR}$ 配合顆粒な ぞ含まれる複数の有効成分が単独では上市されてい ない配合剂については，1 製剤を 1 薬剤として解析 を行った。本研究においては，服用薬剤中に同一の CYP 分子種における競合が 2 つ以上含まれる場 合，及び競合と阻害が含まれる場合を代謝過程にお ける「潜在的 DDI あり」と定義した，なお，本研 究では, 誘導 (酵素誘導) の影響については添付文 書あるいは IF の情報のみからでは競合・阻害へ与 える影響が不明であるため，検討から除外した。

また，本研究においては「薬局におけるハイリス ク薬の薬学的管理指導に関する業務ガイドライン
Table 1. Characteristics of Patients, According to a) Sex and b) Age

\begin{tabular}{lrc}
\hline \hline & Number and percentage of cases \\
\hline a) Sex & & \\
Male & 404 & $43.7 \%$ \\
Female & 520 & $56.3 \%$ \\
Overall & 924 & $100.0 \%$ \\
b) Age (years) & & \\
$0-9$ & 6 & $0.7 \%$ \\
$10-19$ & 2 & $0.2 \%$ \\
$20-29$ & 4 & $0.4 \%$ \\
$30-39$ & 13 & $1.4 \%$ \\
$40-49$ & 47 & $5.1 \%$ \\
$50-59$ & 75 & $8.1 \%$ \\
$60-69$ & 173 & $18.7 \%$ \\
$70-79$ & 326 & $35.3 \%$ \\
$80-89$ & 241 & $26.1 \%$ \\
$90+$ & 37 & $4.0 \%$ \\
Overall & 924 & $100.0 \%$ \\
$65+$ & 719 & $77.8 \%$ \\
\hline
\end{tabular}

（第 2 版）」 ${ }^{8}$ 基づき，抗悪性腫瘍剂，免疫抑制剂， 不整脈用剂，抗てんかん剂，血液凝固阻止剂，ジギ タリス製剤，テオフィリン製剂，精神神経用剤，糖 尿病用剂，膵臓ホルモン剂，及び抗 HIV 用剂をハ イリスク薬と定義して解析を行った。

4. 倫理的配慮 本研究は, 厚生労働省「人を 対象とする医学系研究に関する倫理指針」を遵守 し, 就実大学・就実短期大学 教育・研究倫理安全 委員会（受付番号 205）の承認を得て実施した.

\section{結果}

1. 患者背景 本研究の対象患者は 924 名であ り，男性 404 名 $(43.7 \%)$ ，女性 520 名 (56.3\%) であった。対象患者の年齢構成は 0-9 歳が 6 名 (0.7\%)，10-19 歳が 2 名 $(0.2 \%), 20-29$ 歳が 4 名 (0.4\%)，30-39 歳が 13 名 $(1.4 \%) ， 40-49$ 歳が 47 名 $(5.1 \%) ， 50-59$ 歳が 75 名 $(8.1 \%) ， 60-69$ 歳が 173 名 $(18.7 \%), 70-79$ 歳が 326 名 $(35.3 \%), 80-$ 89 歳が 241 名 $(26.1 \%), 90$ 歳以上が 37 名 (4.0\%) であった．また， 65 歳以上は 719 名であり，全体 の $77.8 \%$ を占めた（Table 1). 服用薬剂数は延べ 4211 薬剤 (371 種類)，平均服用薬剂数は 4.5 剂で あった。

2. 潜在的 DDI の発生頻度 対象患者 924 名 のうち 614 名 $(66.5 \%)$ に代謝過程における潜在的 


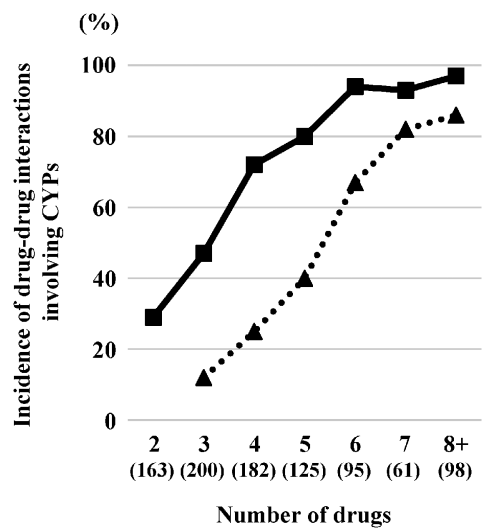

Fig. 1. Incidence of Drug-Drug Interactions Involving CYPs Drug-drug interactions between two or more drugs, the metabolic processes of which involved the same CYP species (solid line). Drug-drug interactions among three or more drugs, the metabolic processes of which involved the same CYP species (dotted line). The number of patients is indicated in parentheses.

DDI があると判断された. Figure 1 には服用薬剤 数に応じた潜在的 DDI の発生頻度を示す．潜在的 DDI の発生頻度は服用薬剂数が増加するほど高く なる傾向であり，代謝過程に同一の CYP 分子種が 関与する 2 種類以上の薬剤による潜在的 DDI の発 生頻度は服用薬剤数が 6 剂の場合は $93.7 \%, 7$ 剂の 場合は 93.4\%，8 剤以上の場合は 96.9\% と服用薬剤 数が 6 凨以上の場合ではいずれも $90 \%$ を超えてい た。また，代謝過程に同一の CYP 分子種が関与す る 3 種類以上の薬剤による潜在的 DDI は，服用薬 剂数が 6 剂の場合は $67.4 \%, 7$ 剂の場合は $82.0 \%$, 8 剂以上の場合は $85.7 \%$ と服用薬剂数が 6 剂以上の 患者の半数以上で認められた.

3. 潜在的 DDI に関与した CYP 分子種の特徵 服用薬剂数に応じた患者あたりの潜在的 DDI に 関与した CYP 分子種の数を Fig. 2 に示す. 潜在的 DDI の発生頻度と同様に，潜在的 DDI に関与した CYP 分子種の数は薬剂数の増加に伴い増加する傾 向が認められた. 特に, 2 種類以上の薬剤による潜 在的 DDI を対象とすると, 関与する CYP 分子種 の数は服用薬剤数が 7 剂以上では 2 を超えていた.

服用薬剂数と潜在的 DDI に関与した CYP 分子 種の種類の関係を Fig. 3 に示す。いずれの服用薬 剂数においても潜在的 DDI に関与する CYP 分子 種は主に CYP3A4 であった。CYP3A4 に関与する 薬剂の服用数は，服用薬剂数が 7 剂の患者において は平均 $3.52 \pm 1.56$ 剂であり，これは 7 剂服用する 患者では CYP3A4 関連の潜在的 DDI に関与した薬

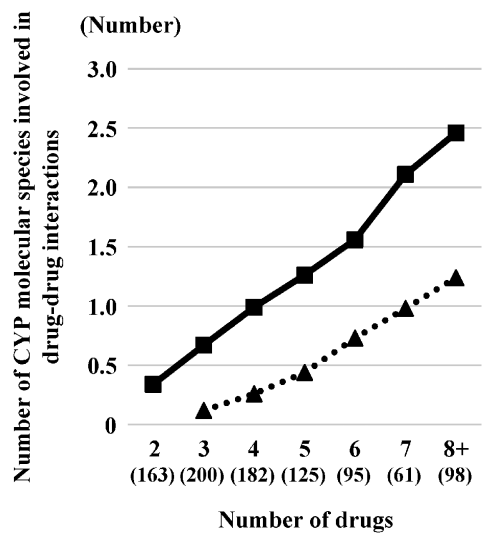

Fig. 2. Relationship between the Number of CYPs Involved in Drug-Drug Interactions and the Number of Drugs

Drug-drug interactions between two or more drugs, the metabolic processes of which involved the same CYP species (solid line). Drug-drug interactions among three or more drugs, the metabolic processes of which involved the same CYP species (dotted line). The number of patients is indicated in parentheses.

剂を平均 3.52 剂服用していたことを示している. 同様に, 8 剂以上の患者においては平均 $4.20 \pm 1.78$ 剤の潜在的 DDI に関与した代謝過程に CYP3A4 が 関与する薬剤を服用していた。

4. 潜在的 DDI に関与した薬剤の特徵＼cjkstart本研 究においては 164 種類の薬剤が潜在的 DDI に関与 しており，医薬品コードに基づき分類した結果，中 枢神経系用薬が $29.9 \%$ と最も多く，ついで循環器 官用薬 24.4\%，その他の代謝性医薬品 9.8\%の順で あった。また， 164 種類の薬剤のうち 61 種類 (37.2\%) がハイリスク薬であり，精神神経用剤 23 種類, 糖尿病用剂 13 種類, 不整脈用剂 9 種類が含 まれた。一方で，処方された場合に潜在的 DDIに 関与する頻度を調査したところ，アルカロイド系麻 薬（コデインリン酸塩水和物など） $100.0 \% （ 2 / 2$ 件), 泌尿生殖器官（タムスロシン塩酸塩など）及 び肛門用薬（メリロートエキスなど） $84.1 \% （ 58 /$ 69 件), 腫瘍用薬（ゲフィチニブなど） $83.3 \% （ 5 /$ 6 件)，抗生物質製剂（クラリスロマイシンなど） $78.6 \%(11 / 14$ 件)，アレルギー用薬（エピナスチ ン塩酸塩など） $78.4 \%$ (87/111 件)，中枢神経系用 薬（ゾピクロンなど） $76.1 \%$ （325/427 件）であっ た。また，潜在的 DDI に関与した延べ 1970 薬剈の うち潜在的 DDI に関与した回数が多い薬剤は，ア ムロジピンベシル酸塩（233 件，循環器官用薬， CYP3A4)，ロスバスタチンカルシウム（126 件, 循環器官用薬, CYP2C9 $2 \mathrm{C} 19 \cdot 2 \mathrm{D} 6 \cdot 3 \mathrm{~A} 4)$, ア 


\begin{tabular}{|c|c|c|c|c|c|c|c|}
\hline \multicolumn{8}{|l|}{ CYP1A1 } \\
\hline CYP1A2 & & & & $0.10 \pm 0.47$ & & $0.20 \pm 0.60$ & $0.28 \pm 0.71$ \\
\hline \multicolumn{8}{|l|}{ СYР2B6 } \\
\hline CYP2C8 & & & & & & & $0.19 \pm 0.62$ \\
\hline СYP2C9 & & $0.17 \pm 0.56$ & $0.35 \pm 0.78$ & $0.43 \pm 0.85$ & $0.57 \pm 0.94$ & $0.93 \pm 1.20$ & $1.41 \pm 1.43$ \\
\hline CYP2C19 & & & & $0.24 \pm 0.65$ & $0.41 \pm 0.86$ & $0.62 \pm 0.98$ & $0.78 \pm 1.06$ \\
\hline CYP2D6 & & $0.17 \pm 0.56$ & $0.16 \pm 0.58$ & $0.10 \pm 0.53$ & $0.39 \pm 0.81$ & $0.72 \pm 1.12$ & $0.81 \pm 1.20$ \\
\hline \multicolumn{8}{|l|}{ CYP2E1 } \\
\hline CYP3A4 & $0.50 \pm 0.87$ & $1.01 \pm 1.15$ & $1.61 \pm 1.27$ & $2.09 \pm 1.31$ & $2.91 \pm 1.35$ & $3.52 \pm 1.56$ & $4.20 \pm 1.78$ \\
\hline \multirow[t]{2}{*}{ CYP3A5 } & & & & & & & $0.12 \pm 0.48$ \\
\hline & $\begin{array}{l}2 \text { drugs } \\
\text { (163) }\end{array}$ & $\begin{array}{l}3 \text { drugs } \\
\text { (200) }\end{array}$ & $\begin{array}{l}4 \text { drugs } \\
\text { (182) }\end{array}$ & $\begin{array}{l}5 \text { drugs } \\
\text { (125) }\end{array}$ & $\begin{array}{l}6 \text { drugs } \\
\text { (95) }\end{array}$ & $\begin{array}{l}7 \text { drugs } \\
\text { (61) }\end{array}$ & $\begin{array}{c}8 \text { above } \\
\text { (98) }\end{array}$ \\
\hline
\end{tabular}

under 1.00

$1.00-1.99$

$2.00-2.99$

3.00 above

Fig. 3. Relationship between the Types of CYP Species Involved in Drug-Drug Interactions and the Total Number of Drugs Taken by the Patient

Each number shows the average number of drugs involved in potential DDIs taken by the patients. Values are mean \pm S.D. A blank cell indicates the mean value is under 0.10 . Only CYP molecular species that were involved in drug-drug interactions in this study are shown. The number of patients is indicated in parentheses.

トルバスタチンカルシウム水和物（83 件，循環器 官用薬，CYP3A4)，ビソプロロールフマル酸塩 (77 件, 循環器官用薬, CYP2D6・3A4), ランソプ ラゾール（76 件，消化器官用薬，CYP2C19・3A4) であり，いずれの薬剤においても CYP3A4 が関与 していた（Table 2).

\section{考察}

医薬品による副作用を予測し，未然回避や早期発 見による重篤化回避につなげるために，DDI に関 する知見は極めて重要である。しかし，現在の添付 文書に記載された DDI は 2 薬剤間に関するもので あり，実臨床においては 3 種類以上の薬剤による DDI に関する知見が望まれる。そこで本研究で は，代謝過程にCYP が関与する薬剤に着目し，服 用薬剂数と代謝過程におけるDDI の関係について 後方視的に調查した.

本研究における平均服用薬剂数は 4.5 剂と厚生労 働省による報告1)より多い結果となった。これは, 本研究においては 2 剂以上を服用している患者を対 象としたことが影響したと考えられる．また，対象 患者の $77.8 \%$ が 65 歳以上と高齢者が多く，研究を 実施した地域の特徵を反映している結果であると思
Table 2. Top 10 Drugs in Which Frequently Involved in Potential Drug-Drug Interactions

\begin{tabular}{|c|c|c|c|c|}
\hline \multirow[b]{2}{*}{1} & \multirow{2}{*}{$\begin{array}{c}\text { Objective drug } \\
\text { Amlodipine Besilate }\end{array}$} & \multirow{2}{*}{$\begin{array}{c}\begin{array}{c}\text { Number } \\
\text { of cases }\end{array} \\
233\end{array}$} & \multicolumn{2}{|c|}{$\begin{array}{l}\text { CYP molecular species } \\
\text { which involved in } \\
\text { potential DDIs }\end{array}$} \\
\hline & & & $3 \mathrm{~A} 4$ & $\mathrm{C}$ \\
\hline 2 & Rosuvastatin Calcium & 126 & $\begin{array}{c}2 \mathrm{C} 9,2 \mathrm{C} 19,3 \mathrm{~A} 4 \\
2 \mathrm{D} 6\end{array}$ & $\begin{array}{c}\mathrm{C} \\
\mathrm{C} \cdot \mathrm{I}\end{array}$ \\
\hline 3 & $\begin{array}{l}\text { Atorvastatin Calcium } \\
\text { Hydrate }\end{array}$ & 83 & $3 \mathrm{~A} 4$ & $\mathrm{C}$ \\
\hline 4 & Bisoprolol Fumarate & 77 & 2D6, 3A4 & $\mathrm{C}$ \\
\hline 5 & Lansoprazole & 76 & $2 \mathrm{C} 19,3 \mathrm{~A} 4$ & $\mathrm{C}$ \\
\hline 6 & Febuxostat & 57 & $\begin{array}{l}\text { 1A1, 1A2, 2C } 8 \\
2 \mathrm{C} 9,3 \mathrm{~A} 4,3 \mathrm{~A} 5\end{array}$ & $\mathrm{C}$ \\
\hline 7 & $\begin{array}{l}\text { Pitavastatin Calcium } \\
\text { Hydrate }\end{array}$ & 53 & $2 \mathrm{C} 9$ & $\mathrm{C}$ \\
\hline 8 & Nifedipine & 51 & $3 \mathrm{~A} 4$ & $\mathrm{C}$ \\
\hline 9 & Rebamipide & 47 & $3 \mathrm{~A} 4$ & $\mathrm{C}$ \\
\hline 10 & $\begin{array}{l}\text { Esomeprazole } \\
\text { Magnesium Hydrate }\end{array}$ & 46 & $2 \mathrm{C} 19,3 \mathrm{~A} 4$ & $\mathrm{C}$ \\
\hline 10 & Brotizolam & 46 & $3 \mathrm{~A} 4$ & $\mathrm{C}$ \\
\hline
\end{tabular}

C: competing interaction, I: inhibitory interaction.

われる。実際に，平成 28 年度の 75 歳以上の院外処 方 1 件あたりにおける薬剤種類数が 4.64 種類であ ること11) は，本結果の妥当性を支持するものであ る。服用薬剤における潜在的 DDI の発生頻度を調 査したところ， $66.5 \%$ の患者に代謝過程における 
CYP が関与する潜在的 DDI が認められた．以前の 研究では，入院患者及び外来処方における潜在的 DDI は $10 \%$ 程度であったことが報告されてお り, ${ }^{9,10)}$ 本研究ではこの数值よりも高い頻度で潜在 的 DDI が確認された。これは，本研究においては 対象者は 65 歳以上の割合が $77.8 \%$ と高く， 1 剤の みの処方を調查対象から除外していることによると 考えられる。一方で，5剂以上を服用する 65 歳以 上の入院患者を対象とした検討では，潜在的 DDI の発生頻度は $80 \%$ を超えていたことが示されてお り, ${ }^{11)}$ この結果は, 特に 2 種類以上の薬剤による潜 在的 DDI に関する本研究結果を支持するものであ る. 本研究では 1 剂のみの処方を調査対象から除外 しているため, 本研究における処方薬の薬効分類等 の概要を全国規模の処方データと比較検討をするこ とはできない。しかしながら，高齢化の進展に伴い 服用薬剤数が増加し，それにより DDI の発生率が 上昇する可能性を考慮すると，本研究により得られ た結果は，わが国における DDI と ADR の関連を 考察する上で有用であると考える。

DDI の発生頻度と服用薬剂数の関連について調 查したところ，潜在的 DDI の発生頻度は服用薬郕 数が増えるに従って上昇しており，潜在的 DDI に 関与する CYP 分子種の数においても同様の傾向で あった．医薬品副作用データベース（Japanese Adverse Drug Event Report database; JADER）を用い て抗凝固薬を投与されている心房細動患者における 出血率とDDI の関連について検討した研究では, 薬物動態学的 DDI を有する患者では, DDI を有し ない患者に比べて出血率は 1.74 倍であったことが 示されている.12) これらのことから，服用薬剂数が 増加することで潜在的 DDI の発生頻度が高くな る，あるいは DDI の強度が強まることにより，実 際の ADR 発生頻度も高くなる可能性が推察され る. 以前の研究において, 服用薬剂数が 6 剂以上で は ADR の発生率が有意に上昇することが報告され ている. ${ }^{2)}$ 本研究では， 6 剂以上服用する患者の半 数以上で 3 種類以上の薬剂による潜在的 DDI が認 められ，さらに，7 剂以上服用する患者では CYP3A4 関連の潜在的 DDI に関与した薬剂を平均 で 3 種類以上服用していた。 したがって，本研究で 得られたこれらの知見は，代謝過程に同一の CYP 分子種が関与する 3 種類以上の薬剤による DDI が
ADR の発生率に一定の影響を与えている可能性を 示唆していると考えられる。一方，CYP3A4 に加 え複数の代謝経路を有する薬剤の場合, 代謝過程に 同一の CYP 分子種が関与する薬剤を併用したこと によりかならずしも血中濃度が上昇するとは言い切 れず，これは本研究における研究限界の 1 つであ る.また， 3 種類以上の薬剤による DDI と ADR の 関連については十分には検討されておらず，ADR の発生率や重篤度等について更なる検討が必要であ るが，ADR の発生に寄与する可能性のある因子を 抽出し，注意深くモニタリングを行うことは臨床上 重要であると考えられる.

潜在的 DDI に関与した薬剤の薬効分類別では, 中枢神経系用薬, 循環器官用薬，及びその他の代謝 性医薬品が多く，これまでにDDI を起こし易い薬 剤として報告されているメトトレキサート（腫瘍用 薬)，ワルファリン（血液・体液用薬）とは異なる

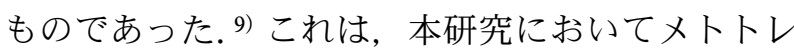
キサートは添付文書及び IF のみでは関与する CYP 分子種を特定できなかったため, ワルファリンは服 用患者が 16 名であったことなど，本研究の手法や 患者背景も影響していると思われる，処方された場 合に潜在的 DDI に関与した頻度の高い薬剤として は，アルカロイド系麻薬（コデインリン酸塩水和物 など)，抗生物質製剤（クラリスロマイシンなど）, 及びアレルギー用薬（エピナスチン塩酸塩など）と いった感冒症状などで一時的に服用することが多い 薬凨が多いことが示された，そのため，常用薬に加 えてこれらの薬剤が処方された場合は，DDIによ りADR のリスクが高くなる可能性がある，本研究 結果に基づき，処方された場合に潜在的 DDI に関 与する頻度の高い薬剤，あるいは潜在的 DDI に関 与する薬剤のうち処方頻度の高いものをあらかじめ 把握することは, 臨床現場における 3 種類以上の薬 剂による DDI に起因する副作用の早期発見のため のより注意深いモニタリングなどへの活用につなが ると考えられる。

本研究は, 外来患者を対象に服用薬剂数と CYP が関与する代謝過程における DDI の関係について 年齢や診療科の制限を設けることなく幅広く調査し, 6 剂以上を服用する患者の半数以上で 3 種類以上の 薬剤による潜在的 DDI が発生していること，すな わち, 同一の CYP 分子種が潜在的 DDI に関与し 
た薬剤が 3 種類以上投与されていたことを見い出し た。また，特に 7 剂以上を服用する患者では代謝過 程に CYP3A4 が関与する潜在的 DDI に関与した薬 剂を平均 3 種類以上内服しており， 3 種類以上の薬 剂が関与する DDI による副作用早期発見の観点か ら注意深く服用後のモニタリングを実施することの 必要性が示唆された。さらに，処方された場合に潜 在的 DDI に関与する頻度が高い薬剤は，アルカロ イド系麻薬や抗生物質製剤，アレルギー用薬など一 時的な服用を目的として処方される場合のある薬剤 が含まれていることが示され，これらの薬剤と常用 薬の DDIにより，特に，これらの薬剤単独あるい は常用薬のみの服用時には問題とならない ADR の 発生に注意することの必要性が示唆された。一方 で，今回の検討では薬剤による酵素誘導については DDI の対象から除外しており，患者背景や解析手 法におけるいくつかの研究限界から，完全には実際 の DDI の有無を反映できていない可能性は否定で きない。そのため, 同一の CYP 分子種が DDI に 関与する 3 種類以上の薬剤が併用された場合の ADR について，その発生率や重篤度，ADR の発 生率を上昇させる医薬品の組合せ等の前向きコホー 卜研究による詳細な検討が必要である。しかしなが ら，本研究結果は実臨床におけるDDI に関する重 要な知見であり, 本研究結果に基づく服用後の自覚 症状や血液検査結果等の注意深いモニタリングによ り安全な薬物治療の提供につながると期待される.

\section{謝辞本研究を実施するにあたり，ご協力を賜} りました岡山県薬剂師会児島支部の保険薬局の皆様 に御礼申し上げます。

利益相反＼cjkstart開示すべき利益相反はない.

\section{REFERENCES}

1) Ministry of Health, Labour and Welfare. "Statistics of Medical Care Activities in Public Health Insurance.": 〈https://www.mhlw.go. jp/toukei/list/26-19c.html $\rangle$, cited 4 October, 2020.
2) Kojima T., Akishita M., Kameyama Y., Yamaguchi K., Yamamoto H., Eto M., Ouchi Y., Geriatr. Gerontol. Int., 12, 761-762 (2012).

3) Perrone V., Conti V., Venegoni M., Scotto S., Degli Esposti L., Sangiorgi D., Prestini L., Radice S., Clementi E., Vighi G., Clinicoecon Outcomes Res., 6, 505-514 (2014) .

4) Giardina C., Cutroneo P. M., Mocciaro E., Russo G. T., Mandraffino G., Basile G., Rapisarda F., Ferrara R., Spina E., Arcoraci V., Front. Pharmacol., 9, 1-12 (2018).

5) Dechanont S., Maphanta S., Butthum B., Kongkaew C., Pharmacoepidemiol. Drug Saf., 23, 489-497 (2014).

6) The First Academic Subcommittee of Japanese Society of Pharmaceutical Health Care and Sciences. "How to Manage Drug Interactions in Clinical Settings.": 〈https:// jsphcs.jp/file/asc1.pdf $\rangle$, cited 4 October, 2020.

7) Ministry of Health, Labour and Welfare. "Guideline on drug interaction for drug development and appropriate provision of information.": 〈https://www.pmda.go.jp/files/ 000225191.pdf $\rangle$, cited 4 September, 2020.

8) Japan Pharmaceutical Association: 〈https:// www.nichiyaku.or.jp / assets / uploads / phar macy-info/high_risk_guideline_2nd.pdf $\rangle$, cited 4 October, 2020.

9) Toivo T. M., Mikkola J. A., Laine K., Airaksinen M., Res. Social Adm. Pharm., 12, 559568 (2016).

10) Gonzaga de Andrade Santos T. N., Mendonça da Cruz Macieira G., Cardoso Sodré Alves B. M., Onozato T., Cunha Cardoso G., Ferreira Nascimento M. T., Saquete Martins-Filho P. R., Pereira de Lyra D. Jr., Oliveira Filho A. D., PLoS One, 15, e0235353 (2020).

11) Doan J., Zakrzewski-Jakubiak H., Roy J., Turgeon J., Tannenbaum C., Ann. Pharmacother., 47, 324-332 (2013).

12) Momo K., Kobayashi H., Sugiura Y., Yasu T., Koinuma M., Kuroda S. I., PLoS One, 14, e0225297 (2019). 